\title{
T0514による豪雨災害時における 気象情報の有効性について \\ EFFICIENCY OF METEOROLOGICAL INFORMATION IN THE CASE OF HEAVY RAINFALL DISASTER BY TYPHOON NO.14 2005
}

\author{
辻本浩史 1 ・後藤祐輔 2 -竹下 航 $^{3} \cdot$ 田中 創 3 \\ Hirofumi TSUJIMOTO, Yusuke GOTOH, Wataru TAKESHITA and Sou TANAKA \\ 1正会員 博 (工）（財）日本気象協会 本社（干170-6055 東京都豊島区東池袋3-1-1） \\ 2 (財) 日本気象協会 首都圈支社（干170-6055 東京都豊島区東池袋3-1-1） \\ 3 (財) 日本気象協会 本社（干170-6055 東京都豊島区東池袋3-1-1）
}

\begin{abstract}
The large and severe typhoon No.14 passed through along the west Kyusyu on September $4^{\text {th }}-7^{\text {th }}$, 2005. The speed of typhoon was low, so, the heavy rainfall continued for a long time. Total rainfall of many observation points exceeded the maximum record and the water level of Ooyodo River, Komaru River and Gokase River exceeded the high water. 15,000 or more people in Miyazaki city and 50,000 or more people in Nobeoka city were ordered to refuge. A lot of meteorological information was able to get by internet-web-sites . Among them, the accuracy of the forecast information of 24 hours rainfall and the efficiency of the spatial and temporal information of flood risks was verified. As the results, it was shown that these information which support self-help, co-help of inhabitants are useful for the disaster prevention.
\end{abstract}

Key Words : flood risk, rainfall prediction, meteorological information, disaster prevention

\section{1.はじめに}

平成17年8月29日にマリアナ諸島付近の近海で発生し た台風14号は，西に進みながら大型で非常に強い勢力に 発達し，その後日本の南海上を北西に進んだ後，9月4日 〜6日にかけて九州西岸を北上した. 例年に比べて偏西 風が北にシフトしていたために, 転向・北上後の速度も $20 \mathrm{~km}$ 程度と遅く，九州南部を中心にして長時間にわたり 暴風域の影響を受け続けた。降り始めからの雨量は，九 州と四国地方の各地で例年の9月月間平均雨量の2倍を超 える豪雨となった。

この大雨の影響で, 九州, 四国, 中国地方の河川で水 位が上昇し，特に，宮崎県の大淀川，小丸川，五ヶ瀬川 では計画高水位を超える規模の洪水となった。この結果， 大淀川，五ヶ瀬川で大規模な浸水被害が生じ，宮崎県全 体では10万人を越える県民に避難指示が出された.

大型で非常に強い台風がゆっくりと接近してきたこと から，台風の進路予測や気象庁の気象警報など，多くの 防災情報が事前に発表され，住民一警戒を呼びかけた。
また，国，自治体および民間気象会社の公開Webサイト （例えば，http://tenki.jp）等を通じて，様々なリア ルタイム情報が閲覧可能であった. 平成16年に多発した 豪雨災害から時間が経過していないこともあり，一般住 民の気象情報に対する意識は非常に高かったと思われる.

平成16年度の豪雨災害をふまえ，著者ら ${ }^{1)}$, 2 は, 洪水 災害を軽減するための自助・共助を支援する気象情報の あり方を議論し，洪水被害の危険度をわかり易く表現す る洪水リスクポテンシャル指数 (Index of Flood Risk Potential : 以下IFRiP) を提案した. しかしながら, 洪 水の原因となる豪雨については実況值を用いた解析にと どまっていた.

以上の点を鑑み, 本研究では, 災害時の気象概況につ いて整理するとともに，（財）日本気象協会が開発を進 め, 結果の一部を公開HP (http://www. jwa. or. jp) 上で 公開している局地気象モデルによる降雨予測情報の有効 性を検証した。

また，降雨予測情報と組み合わせたIFRiPを今回の災 害に適用し, 洪水被害を軽減する防災情報としての可能 性を評価した。 


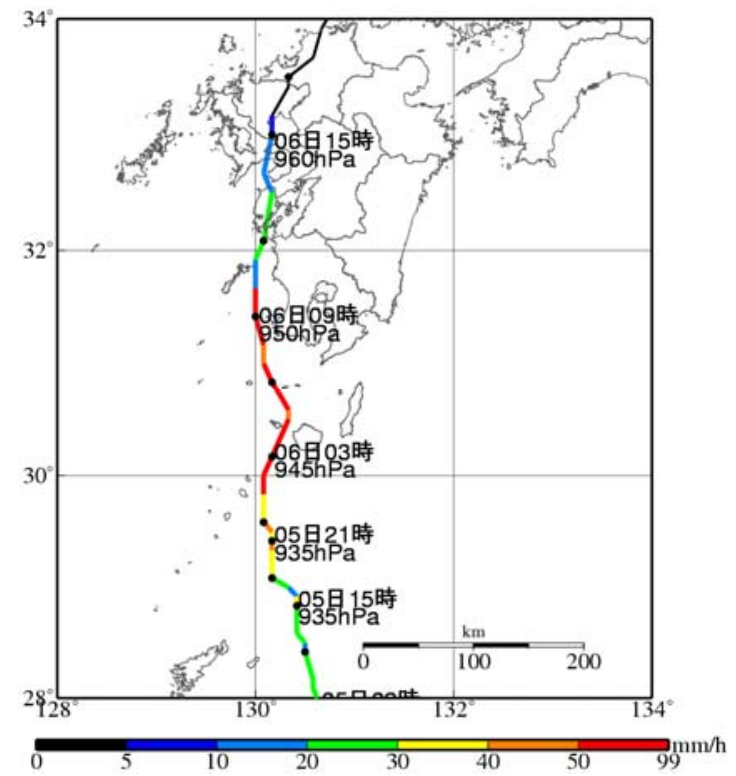

図-1 台風経路図（色分けはアメダス神門の時間降水量）

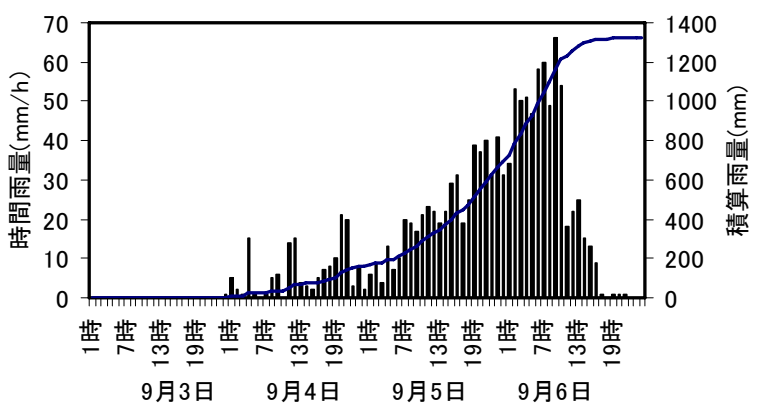

図-2 アメダス神門地点の時間雨量変化図

\section{2. 台風14号の影響による大雨と出水状況}

台風14号の経路を図-1に，アメダス観測所の中で降り 始めからの総雨量が最も多い $1322 \mathrm{~mm}$ 記録した宮崎県南 郷村神門の時間雨量の変化図を図-2に示す。なお，図-1 の経路図は，神門の1時間降水量で着色している.

東海上から断続的に流れ込む雨雲によって，4日から 強い雨が降り始め，5日には雨雲の流入も連続的となり $20 \mathrm{~mm} / \mathrm{h}$ 程度の雨が降り続いた，さらに，台風本体の雨雲 の影響を受けはじめた 5 日 22 時頃からは $40 \mathrm{~mm} / \mathrm{h}$ を超える 激しい雨が降り続き記録的な大雨となった. 図 -3 , 図-4 には，宮崎県内のアメダス観測所データによる総雨量分 布図と最大 1 時間雨量の分布図を示寸。総雨量は，多く の観測所で履歴1位を更新し，海岸線から内陸方向に増 加し，東〜南東風から流入してきた雨雲が最初に上昇す る地域で特に大きな值を示している。，一方，時間雨量に ついては，総雨量に比べて明確な分布はみられず，また， 履歴1位を更新した観測所は無かった。

図-5，図-6は，計画高水位を超え，汇濫被害の生じた 大淀川，五ヶ瀬川の雨量・水位変化図を示している. 大

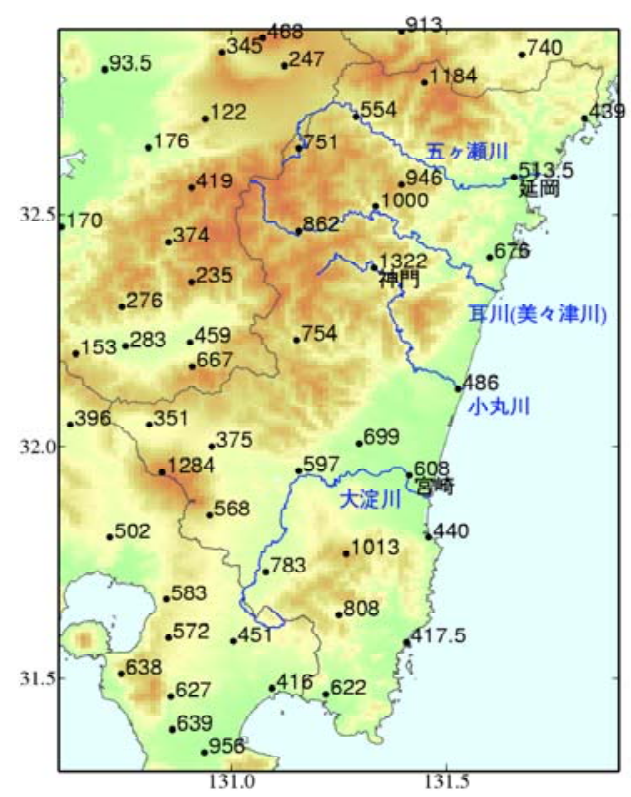

図-3 総雨量分布図

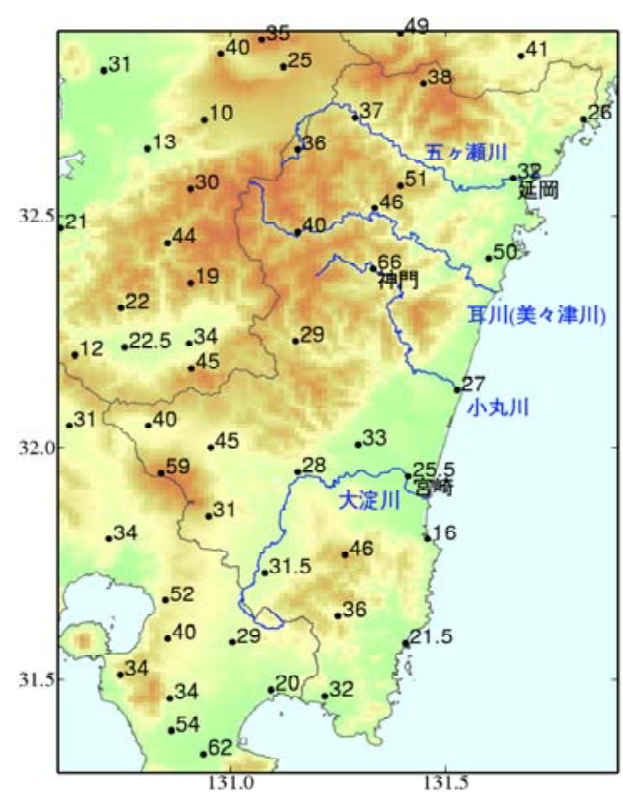

図-4 最大 1 時間雨量分布図

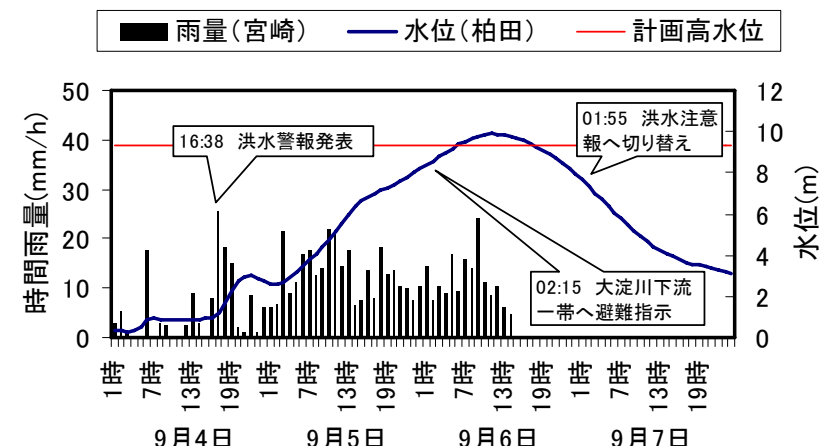

図-5 大淀川の雨量・水位変化 


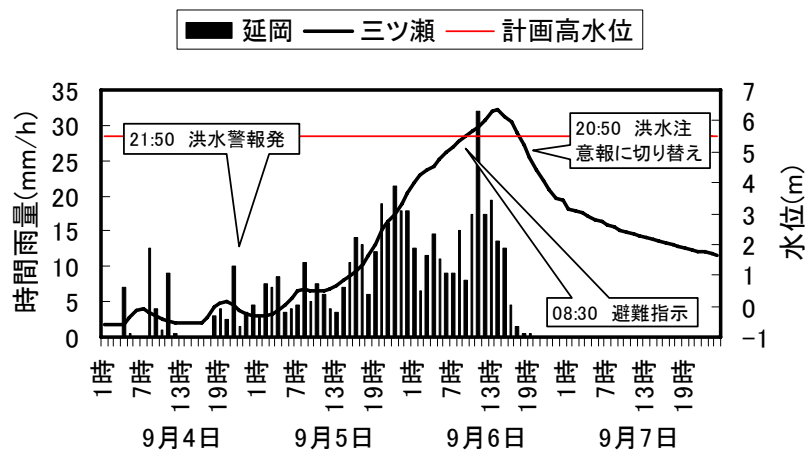

図-6 五ヶ瀬川の雨量・水位変化

淀川では宮崎市内の水位観測点柏田において，9月6日の 6時から17時まで計画高水位9.36mを超えた．五ケ瀬川で は延岡市内の三ツ瀬において，9月6日の10時から17時ま で計画高水位5.53mを超えた。宮崎市では9月6日02時 15 分に大淀川下流域一帯の6, 666世帯, 15,014 人に避難指 示，延岡市では9月6日8時30分に，五ヶ瀬川，大瀬川流 域の 22,736 世帯，52, 975 人に避難指示が出された ${ }^{3)}$. 浸 水，越水が生じた詳細な時間等について現時点では不明 であるが，大淀川では，宮崎市内で6日の午前中から， 五ヶ瀬川では, 延岡市内で午後1時頃から浸水が拡がっ たと推定される. なお，宮崎県では南部平野部に大雨・ 洪水警報が発令された 9 月 4 日16時 38 分に情報連絡本部が, さらに，9月5日14時には災害警戒本部が設置されている. 今回の災害では, 宮崎県内で死者・行方不明者が 12 名 となったが，その多くは，土砂災害によるもので，平成 16年の新潟・福井豪雨と比較すると, 洪水そのものによ る犠牲者は幸いにも減少した。これは，先にも述べたよ うに台風の進行スピードが遅く，住民が迫りつつある大 雨の情報を事前に把握できたこと，破堤による突発的な 浸水が無かったこと，住民の避難が適切なタイミングで 行われたこと等が関係していると思われる.

\section{3. 降雨予測情報の検証}

\section{(1) SYNFOSの概要}

降雨予測モデルは，対象とする現象の時・空間スケー ルに応じて様々なモデルが開発されてきた．夏期の雷雨 のように現象の持続時間が数分から数時間, 空間スケー ルが数km程度の事象に対しては, レーダデータ等の実況 監視データに基づいた運動学的手法が用いられている.

一方，低気圧や台風のように，数日間継続し，空間ス ケールも数十 $\mathrm{km}$ 数百 $\mathrm{km}$ と大きな現象の予測は, 大気の 流れを力学的に記述された方程式系を数值的にシミュ レーショトする物理学的手法が効果的とされている.

物理学的手法としては, 気象庁の数值シミュレーショ ンモデル4)が代表的である. 現在，気象庁では，予測時 間，空間解像度に応じて 3 種類（GSM，RSM，MSM）のモデ
表-1 SYNFOSの概要

\begin{tabular}{|c|c|c|}
\hline \multicolumn{2}{|c|}{ 予報モデル } & $\begin{array}{l}\text { 非静力学予報モデルMM5をベースに物 } \\
\text { 理過程を独自改良 }\end{array}$ \\
\hline \multicolumn{2}{|c|}{ 初期時刻 } & $\begin{array}{l}00,03,06,09,12,15,18,21 \text { 時 } \\
\text { (1日8回，3時間毎) }\end{array}$ \\
\hline \multicolumn{2}{|c|}{ 予測時間 } & 初期時刻〜30時間先まで \\
\hline \multicolumn{2}{|c|}{$\begin{array}{l}\text { 初期值及び } \\
\text { 境界值 }\end{array}$} & $\begin{array}{l}\text { 気象庁領域数値予報モデル(RSM) 及び } \\
\text { メソ数值予報モデル(MSM) を内挿 } \\
\text { 初期値は気象庁ウィンドプロファイラ } \\
\text { 観測值を加えて解析処理 }\end{array}$ \\
\hline \multicolumn{2}{|c|}{ 格子間隔 } & 5km（沖縄は10km） \\
\hline \multicolumn{2}{|c|}{ 予測範囲 } & 日本全域 \\
\hline \multicolumn{2}{|c|}{ 予測発表時刻 } & 初期時刻から4時間15分後（概算） \\
\hline \multirow{2}{*}{$\begin{array}{l}\text { 予測 } \\
\text { 要素 }\end{array}$} & 全層 & $\begin{array}{l}\text { 風の3成分, 気温, 高度偏差, 気圧偏 } \\
\text { 差, 全相水分, 雲水量（水, 水, 雨 } \\
\text { 滴, 雪, 霰), 乱流エネルギー, 相当 } \\
\text { 温位, 渦度, 雲量, 他 }\end{array}$ \\
\hline & $\begin{array}{l}\text { 地上 } \\
\text { のみ }\end{array}$ & $\begin{array}{l}\text { 降水量, 降雪量, 降霰量, 顕熱・潜熱 } \\
\text { フラックス, 上・下向き短波長放射, } \\
\text { 上・下向き長波長放射, 地表面・地中 } \\
\text { 温度, 海面気圧, 他 }\end{array}$ \\
\hline
\end{tabular}

ルをルーチン運用している．これらのモデルのうち，明 日〜明後日の予測を行うのがRSM (Regional Spectral Mode1）であり，12時間毎（初期時刻09時，21時）に， 51 時間先までの気温，風，降水量等を， $20 \mathrm{~km}$ 格子の解像 度で計算している.

しかしながら，国内における河川の流域スケール，ま た, 洪水時における様々な体制の設置・解除のタイミン グを考慮すると， RSMの $20 \mathrm{~km}$ 四方 $\left(400 \mathrm{~km}^{2}\right)$ と 12 時間更 新でも十分とはいえず，より空間解像度が高く, 更新間 隔も短い情報が必要となってくる.

現在、（財）日本気象協会では，RSM，MSMの出力值を 初期条件，境界条件として利用し，さらに高解像度の局 地気象予測を行うSYNFOS (Synnefo Numerical Forecasting System）と呼ばれる総合数值予測システム をルーチン運用している5 . 予測モデルのコアはペンシ ルバニア州立大と NCAR (National Center for Atmospheric Research)により開発された物理学的手法 である非静力学モデルMM5をべースとしている. MM5は, ホームページ上で無償配布されているが，（財）日本気 象協会では物理過程の一部である乱流過程, 地表面過程 の改良等を行い，独自予測として社内利用，社外公開を 行っている. SYNFOSの概要を表-1に示す.

SYNFOSの主たる特徵として, 気象庁ウィンドプロファ 


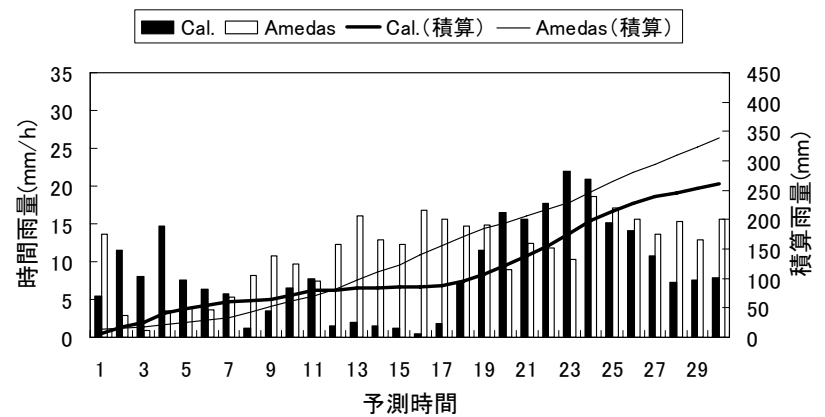

図-7 大淀川流域の予測結果（初期時刻：9月4日18時）

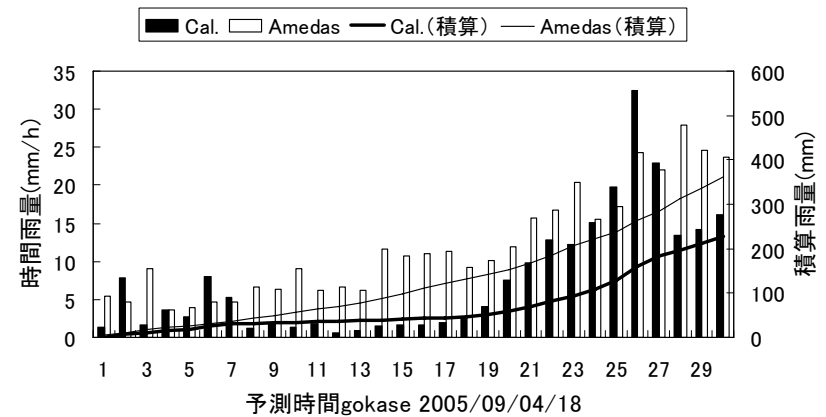

図-8 五ヶ瀬川流域の予測結果（初期時刻：9月4日18時）

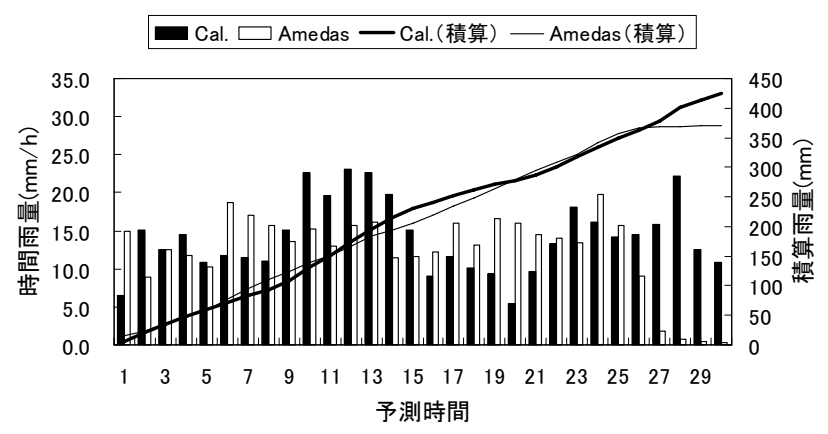

図-9 大淀川流域の予測結果（初期時刻 : 9月5日12時)

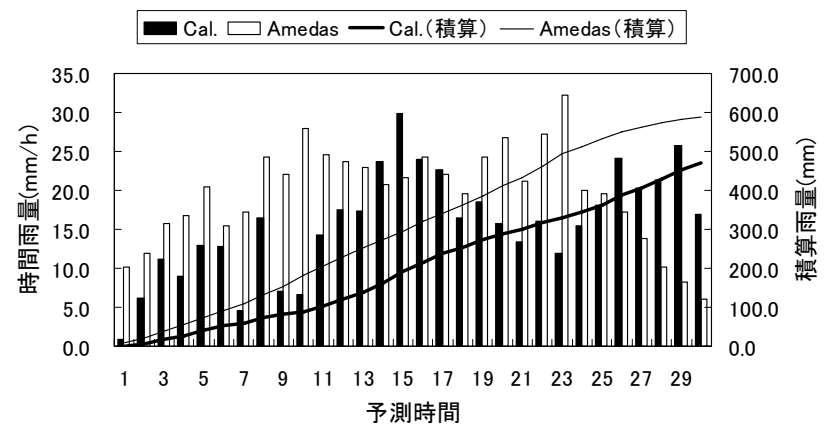

図-10 五ヶ瀬川流域の予測結果（初期時刻：9月5日12時）

イラの観測データを利用することで3時間間隔での初期 值作成を実現した事, また, 計算処理の工夫により, RSMの16倍の解像度をもつ $5 \mathrm{~km}$ 格子の計算を高速で実施で きる点である.

\section{（2）適用結果}

大淀川と五ヶ瀬川を対象とした台風14号時の30時間後 までの予測結果を示す。実測值は流域内のアメダス観測

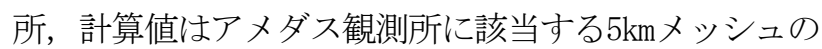
值とし, 流域平均雨量は, これらの值の算術平均とした。

宮崎県南部平野部に大雨・洪水警報が発令された時刻 に近い9月4日18時を初期時刻とした予測結果を，大淀川， 五ヶ瀬川について，それぞれ図-7, 図-8に示す。大淀川 流域では，約5時間後までは過大，約 12 時間後〜18時間 後までは過小，その後は概ね良好な予測結果となってい る. 五ヶ瀬川においても同様の傾向である. 両流域とも 積算雨量では実績より $100 \mathrm{~mm}$ 程度過小予測となっている が，今後 30 時間で南部，北部とも $200 \mathrm{~mm}$ 以上の雨が降り, 一部山間部を除く宮崎県内の大雨警報基準である，24時 間で $200 \mathrm{~mm}$ 以上を越えること，5日午後からは雨が強くな り，流域全体で $15 \mathrm{~mm} \sim 20 \mathrm{~mm} / \mathrm{h}$ の雨が降り続くこと等の状 況が予測できたことは，防災体制の初期における支援情 報としては有効だったと思われる。

さらに，18時間経過した9月5日12時の予測結果を， 図-9, 図-10に示す。この時点では, 台風をとりまく雨 雲が次々と流入し, 流域平均で $10 \mathrm{~mm} / \mathrm{h}$ 程度の雨が降り続 き，河川の水位は，宮崎市内の大淀川で警戒水位を超え つつある状況である．2時間後の14時には宮崎県災害警 戒本部が設置されている.

図-9に示す大淀川の結果では，約27時間先以降の降雨 終了時期における精度が悪いものの，それまでは非常に 高い適合度を示している，一方，図-10に示寸五ヶ瀬川 においては7時間〜11時間先において過小予測傾向が続 くものの，その他は約24時間先まで高い適合度を示して いる. これらの降雨予測結果を洪水予測モデルの入力值 とすることで高精度の水位予測が実施できた可能性が高 く、防災体制の中期における支援情報として有效だった と思われる。

\section{IFRiPIによる洪水リスクの把握}

\section{(1) IFRiPの概要}

平成16年度は平年の 2 倍以上となる10個の台風が上陸し， 各地で発生した洪水汇濫や斜面崩壞等により 200 名以上の 死者・行方不明を出寸結果となった. 特に, 新潟県や福井 県などでは，県が管理する二級河川において破堤，越水が 生じ，大規模な外水汇濫が生じた。これらの災害をうけて 行政が取りまとめた総合的な豪雨災害対策(6)では, 自助・ 共助・公助のバランスのとれた防災対策の重要性とともに, 住民一提供寸る防災情報についても，送り手情報から受け て情報への転換を図るとされている.

現在，洪水予報は県が管理する河川にもその指定を拡大 しつつあるが，平成16年12月時点の整備は19水系29河川と 遅れている状況である. さらに, 山間地域の中小河川まで 
表-2 IFRiPの概要

\begin{tabular}{|l|l|}
\hline 対象範囲 & 日本全域 \\
\hline 格子間隔 & $1 \mathrm{~km}$ \\
\hline 入力 & $\begin{array}{l}\text { レーダアメダス解析雨量および } \\
\text { 降水短時間予報 }\end{array}$ \\
\hline 予測時間 & 初期時刻〜6時間先まで \\
\hline 更新時間 & 30 分間隔 \\
\hline 要素 & IFRiP指数, IFRiP順位值 \\
\hline
\end{tabular}

も対象とすると，きめの細かい 洪水予報の完備には依然と して膨大な時間・コストを要するのが現実である.また， 洪水予報に用いられている流出モデルが貯留関数法に代表 される集中型モデルが多いこと等の理由で，現在，国や県 のHP（例えば，http://www. river. go. jp）で入手できる情 報も，河川毎に数地点と限られており，流域全体の面的情 報として洪水の危険度を認識できる情報とはなっていない

筆者ら ${ }^{1)}$ が提案したIFRiPは，あらかじめ数值標高データ より整備された河道網に基づき，任意メッシュの上流集水 域に降った雨を洪水到達時間内で平均した，いわゆる「洪 水到達時間内の平均降雨強度」であるIFRiP指数と，同様 の手法で作成された1991年以降の過去DB上での順位值であ るIFRiP順位からなる.

洪水到達時間については，クラーヘン式を用いて求めら れた洪水到達時間と流域面積との関係を数多くの流域につ いて集計した結果得られた次式をを用いた。

$$
y=0.0134 x+0.9655
$$

ここに, $y$ : 洪水到達時間 $(\mathrm{hr} r), x$ : 流域面積 $\left(\mathrm{km}^{2}\right)$ で ある.

内水汇濫や外水汇濫の規模と範囲を定量的に評価寸るこ とはできないものの，洪水の危険度を，河川水位という絶 対值ではなく，過去と比較した順位值として，面的に把握 することができる情報である．筆者ら ${ }^{2)}$ は，IFRiPを平成16 年度の災害に適用し，防災支援気象情報としての有効性を 確認してきたが，実運用にむけた河川網整備と，有効性を 更に向上させるための降雨予測情報とのリンクが課題と なっていた，その後，IFRiPを日本国内全域で算出するた めに全国 $1 \mathrm{~km}$ 河道網の整備が進められる一方で，IFRiPに気 象庁の降水短時間予報を組み込む改良も加えられ，新たな 防災支援気象情報として2005年7月より運用を開始した。 IFRiPの概要を表-2に示寸.

\section{（2）適用結果}

図-11は，大淀川下流一帯へ避難指示が出される約1時 間前の9月6日1時を初期時刻としたIFRiPである．1時の 実況では，大淀川，小丸川，五ヶ瀬川においてIFRiP順 位值が2〜5位以内の地域が目立つ程度で，既往最大を越 える箇所はない，ところが，台風本体の強い雨が降り続 くと予測した降水短時間予報值を利用したIFRiP予測值 は，大淀川の順位值が下流域で上昇し，6時間後の7時の
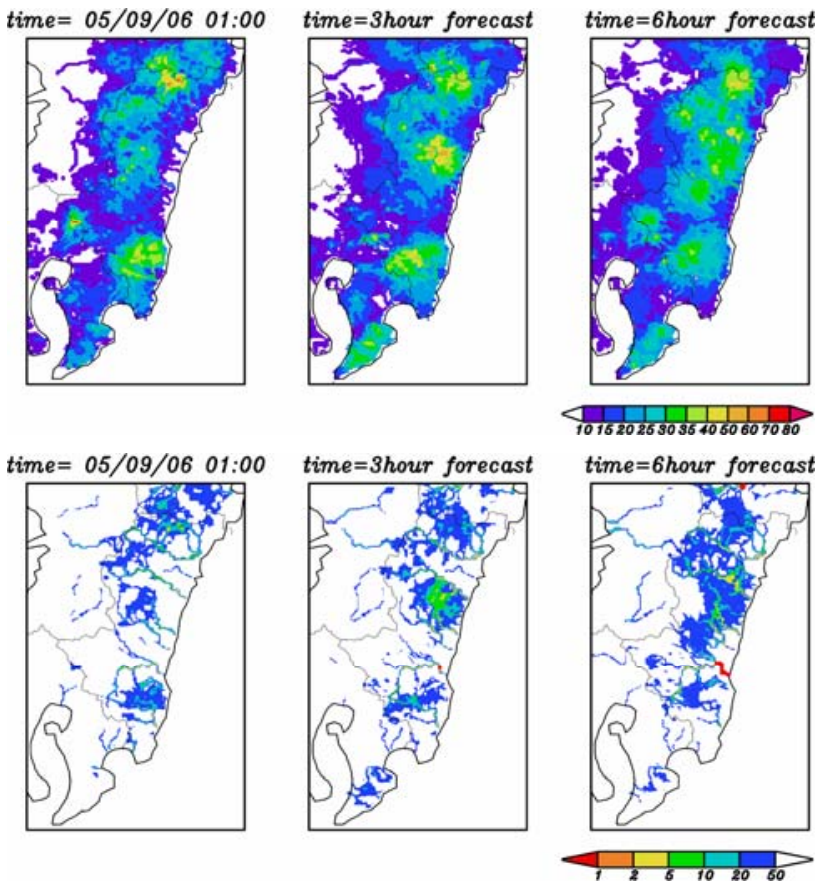

図-11 IFRiPの分布（初期時刻：9月6日1時）

上段：IFRiP指数，下段：IFRiP順位值

左 : 実況 中: 3 時間後 右 : 6 時間後
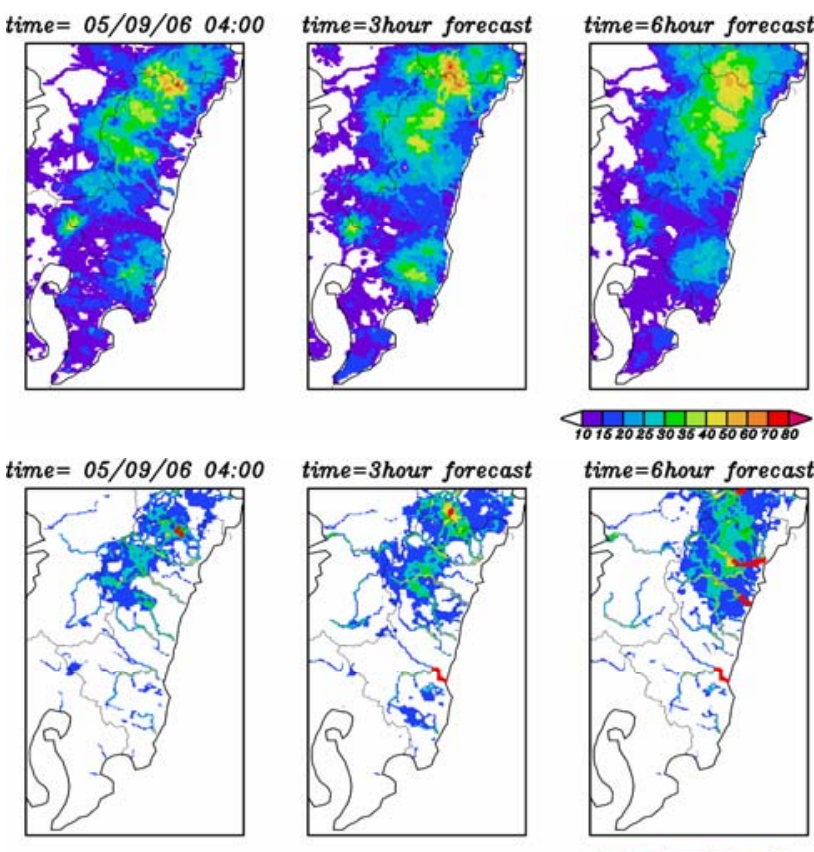

図-12 IFRiPの分布（初期時刻：9月6日4時） 上段 : IFRiP指数, 下段 : IFRiP順位值 左 : 実況 中: 3 時間後 右 : 6時間後

時点では履歴1位の箇所が数多く出現している. 実際に は，宮崎市内の水位観測点では6時に計画高水位を超え ることになる．図-12は，図-11より3時間後の9月6日4時 を初期時刻とした結果である. 大淀川では3 時間後，6時 間後と, 下流部で履歴1位の箇所が出現し, 過去十数年の 中で最も洪水リスクが高まり，3時間後，6時間後と危険な 

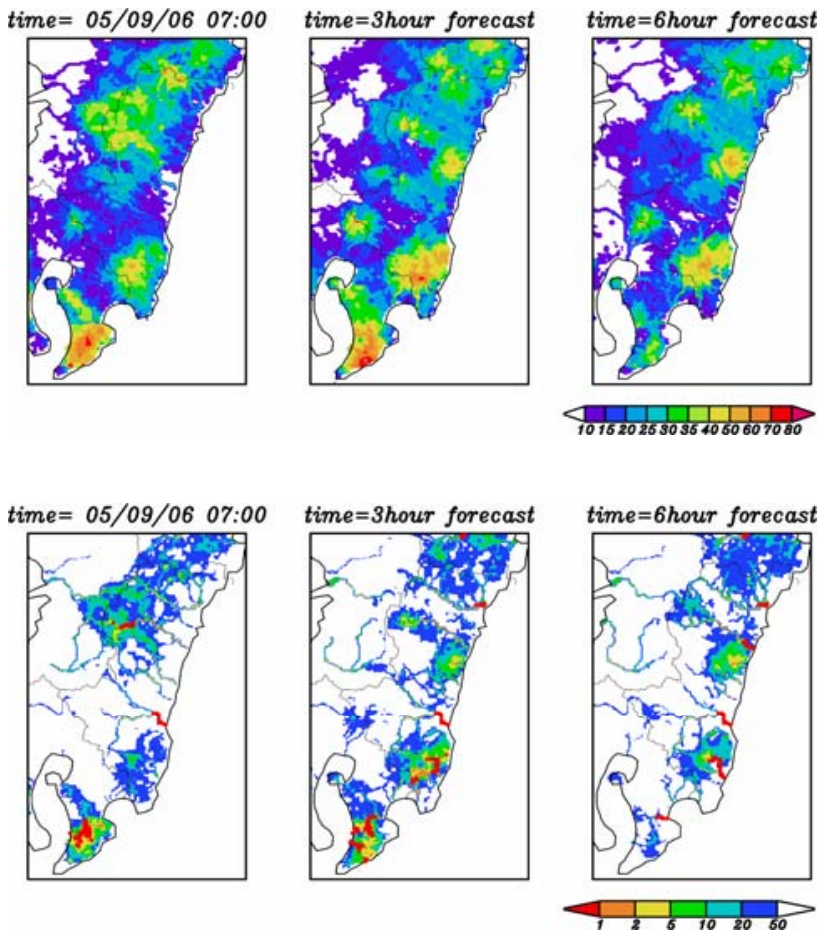

図-13 IFRiPの分布（初期時刻：9月6日7時） 上段：IFRiP指数，下段：IFRiP順位值 左 : 実況 中: 3 時間後 右 $: 6$ 時間後

状態が続くことを示している，一方，北部の五ヶ瀬川では， 4時の実況時点で上流部の小河川の順位值が1位となってい る箇所があるものの，下流部での順位值は履歷2位以下で ある. しかしながら，3時間後の7時，6時間後の10時と中 〜下流部において履歴1位の箇所が数多く出現している. 宮崎と大分の県境付近で降っている激しい雨が，山地小河 川から次々と本川に集められ，洪水となって下流、伝播し ていく状況が把握できる.

図-13は，図-12よりさらに3時間が経過した9月6日7時を 初期時刻としたIFRiPである。この時点で大淀川では水位 が計画高水位を超えてさらに上昇を続けており，北部五ケ 瀬川では, 延岡市の一部地域に避難指示が出される約1時 間前の状況である. 大淀川のIFRiPは依然として下流部で 履歴1位の箇所があり，3時間後，6時間後と同程度の危険 な状態が続くことを示している. 一方，北部の五ヶ瀬川に おいては3時間後の10時，6時間後の13時にかけて，下流部 における洪水リスクが非常に高まっていく危険性を予測し ている. 実際に，五ヶ瀬川の上流部では，11時頃まで $30 \mathrm{~mm}$ 〜40mmの激しい雨が降り続き, 流域に被害をもたらすこと となる. また, 鹿児島の大隅半島にも7時時点, 3 時間後の 10時時点と履歴1位の箇所が出現している. 被害発生の詳 細な時間は不明なものの, 大隅半島の中小河川でも内水や 溢水の被害事例が報告されており ${ }^{8}$ ，IFRiPは同地域におい ても水害発生の危険性を予測していた可能性が高い.

以上のように，降水短時間予報とリンクしたIFRiPは，
台風14号の大雨によって発生した河川の洪水について，そ の規模と発生時期の推移を，広範囲に把握できたことがわ かり，防災支援気象情報としての有效性が確かめられた。

\section{5. 結論}

平成16年度に出された国の豪雨災害緊急アクションプラ ンに「公助、協助、自助」の考え方が盛り込まれた. 災害 の軽減には, 行政が担う公助とともに, 地域, 住民個々の 防災意識を高めることが重要な時代となり，そのためにも， 有効な気像情報を，地域住民に直接，あるいは，地域住民 に接する行政防災担当者に発信していく必要がある. 本研 究では，台風14号時の豪雨災害を対象として，防災支援気 象情報の有効性を検証した。 その結果，

- SYNFOSによる30時間先までの予測雨量は，実測值を 概小良好に予測できた。

- 降水短時間予報とリンクしたIFRiPは, 洪水リスクの 程度と発生時期の推移を広範囲に把握できた.

事がわかった。

今後は，IFRiPの過去DBを，過去の顕著な出水を含む長 期間のDBとして充実させるとともに，降雨予測とIFRiPか ら得られる洪水リスク予測結果を, リアルタイムの浸水シ ミュレーションに接続し，より有効な防災支援情報として 整備していくことが課題である.

\section{参考文献}

1) 辻本浩史, 桜井康博, 後藤祐輔, 石井玩哉 : 自助・共助の防災 活動を支援する情報のあり方に関する考察，日本災害情報学会， 第6回発表大会予稿集，pp. 203，2005.

2) 辻本浩史, 後藤祐輔, 石井玩哉: 洪水リスクポテンシャル情報 の開発と新舄・福井洪水災害一の適用，水工学論文集，第49巻, pp. 481-486, 2005.

3) 宮崎県 : 平成17年9月 4 日からの台風第14号の影響による大雨の 被害状況等について, http://www. pref. miyazaki. lg. jp/.

4) 気象庁編: 気象業務はいま, 2005.

5) 田中 創 : 総合数值予測システムSYNFOS（シンフォス）の $\mathrm{H} 16$ 豪雨事例一の適用，水文・水資源学会2005年研究発表会要 旨集, 2005.

6) 社会資本整備審議会河川分科会, 豪雨災害対策総合政策委員 会 : 総合的な豪雨災害対策の推進について (提言)，国土交通 省河川局, 2005.

7) 中小河川計画検討会編：中小河川計画の手引き (案)，財団法 人国土開発技術研究センター, p. 241, 1999.

8) 国土交通省 : 台風14号と前線豪雨について(第16報 : 最終 報,htttp://www. mlit. go. jp/bosai/disaster/saigai jyouhou.

(2005. 9. 30受付) 